THE AUSTRALIAN JOURNAL OF
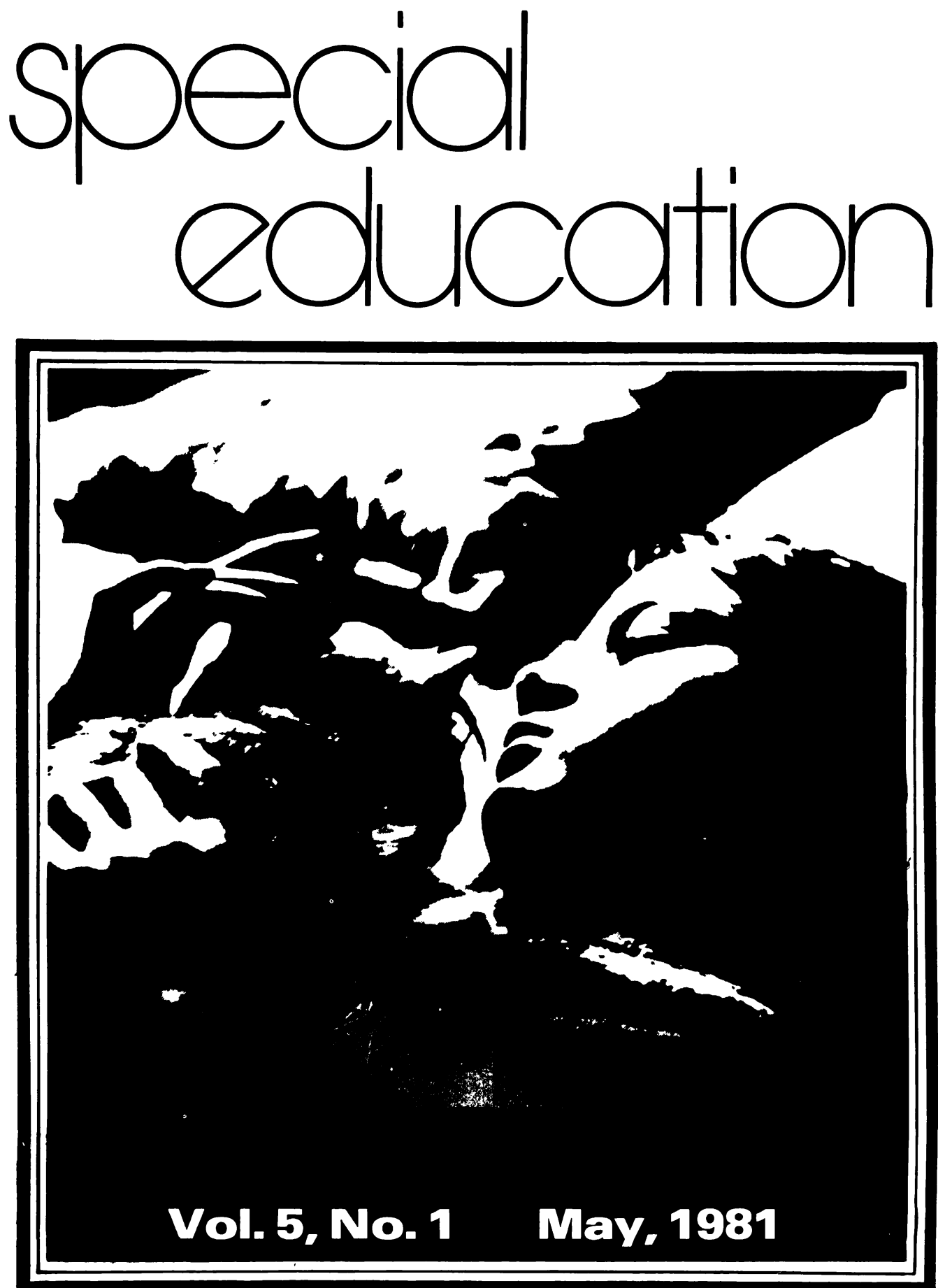

The Cunningham Library - ACER

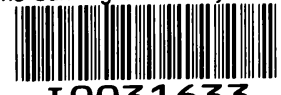

the australian association of special education 


\section{COMPUTERS IN SPECIAL EDUCATION? YES - IN SCHOOLS AND HOMES}

We believe that microcomputers have a very important place in Special Education

- a verbal but non-oral way of teaching the deaf

- stimulating and exciting teaching for the 'motivationally' handicapped

- excellent for interesting repetitive (drillI) teaching for L.D. and M.R.

- easily adapted for use by the physically handicapped

- ideal for enrichment for the gifted (they're great for 'regular' kids tool)

\section{WHAT SORT OF MICRO COMPUTER SHOULD I BUY?}

IT MUST: 1. be durable, expandable and have plenty of RAM

2. be backed by after-sales service

3. have educational software available

4. be compatible with most other schools near you.

SO - Buy the largest selling micro for schools -

\section{THE APPLE ${ }^{\mathrm{TM}}$ COMPUTER}

\section{WHERE DO I BUY?}

\section{BuY from THE TOOWOOMBA COMPUTER CENTRE}

We are experienced special-educators who have been using APPLE in special education settings for the last two years.

We have after-sales and software service.

it Mail order sales and service is NO problem.

We have VERY COMPETITIVE prices.

\section{CALL OR WRITE TO: Mrs. Robyn Bailey, \\ 88 Mary Street, \\ TOOWOOMBA, Q. 4350 \\ $\mathrm{Ph}$ (076) 327542 (A.H.)}

TM Reg. Trademerk of Apple, Inc.

\section{SPECIAL EDUCATION CENTRES OF INTEREST}

\section{AN INVITATION}

In each edition of this Journal, we include a brief report on an interesting Special Education Centre.

The purpose of this feature is to develop awareness of particular agencies which are serving an interesting or unusual role in Special Education.

We hereby invite people to submit articles about Special Education Centres of interest. 


\title{
THE AUSTRALIAN JOURNAL OF SPECIAL EDUCATION
}

\author{
THE OFFICIAL JOURNAL FOR THE AUSTRALIAN \\ ASSOCIATION OF SPECIAL EDUCATION
}

\section{EDITOR}

Dr. Jeff Bailey, Associate Dean (Academic) School of Education, Darling Downs Institute of Advanced Education, P.O. Box 30,

Darling Heights, TOOWOOMBA, QLD. 4350

Phone (076) 301300

\section{NATIONAL EXECUTIVE}

President:

Sen. Vice Pres.:

Jun. Vice Pres.:

Secretary:

Treasurer:
Mr. John Burge (Q.) Mr. John Callanan (Vic.) Ms Heather Martin (N.S.W.)

Mr. Ron Parry (Q.)

Mr. Stuart Stieler (Q.)
Official Address:

Secretary, A.A.S.E.,

P.O. Box 2070,

G.P.O. Brisbane, Q. 4001.

\section{EDITORIAL COMMITTEE}

Dr. Barry Fields,

Darling Downs Institute of Advanced Education, Toowoomba, Q.

Dr. Jim Irvine, University of New England, Armidale, N.S.W.
Dr. Peter O'Connor,

College of Advanced Education, Newcastle, N.S.W.

Miss Pat White, B.Ed., Litt.B., Guidance and Special Education, Toowoomba, Q.

Dr. Keri Wilton, University of Auckland, Auckland, N.Z.

\section{BUSINESS MANAGER}

Mr. John Handley, B.Bus., Director, Education Centre, Toowoomba, Q.

\section{AFFILIATED BODIES}

Association of Special Teachers of Victoria

N.S.W. Association of Special Education Teachers

Queensland Special Education Association

South Australian Association of Special Education

Tasmanian Association of Teachers of Exceptional Children

W.A. Association of Special Education

N.T. Assaciation of Special Education

A.C.T. Association for Professionals Concerned with the Handicapped

\begin{abstract}
Please direct any editorial enquiries or articles for inclusion to the Editor at the above address. Articles submitted should be in line with the theme of the Journal - the delivery of educational services to exceptional children. Articles should be typed, double-spaced on quarto paper on one side only and submitted in duplicate. Additional information required is a brief abstract of the paper (less than 150 words) and details of the author's name, work, experience and qualifications. The Editor bears responsibilty for selecting, accepting and editing the articles. However, the opinions expressed and the accuracy of the papers are the responsibility of the author concerned.
\end{abstract}




\section{THE AUSTRALIAN JOURNAL \\ OF SPECIAL EDUCATION}

Volume 5, No. $1 \quad$ May, 1981

\section{CONTENTS}

Page

Editorial

The A.A.S.E. President's Report: Turning the Corner

John Burge

Statement from Sub-Committee on Teacher Education and Special Education

J. C. P. Duerdoth

Research and Review

Planning to Meet the Special Education Needs of Primary Schools

H. Eldridge and J. Chapman

Agencies Referring Children for Special Class Placement

Diane Bowyer and Elizabeth Constable

Viewpoints and Brief Reports

Computer assisted teaching: two applications in special education

Mike Lally

A Behaviour Management Flow Chart to Generate Specific On-Task

Behaviours in an Educational Context

A. T. Haines

21

Diagnostic Teaching in a High School

Rachel M. Boyd

Special Education Centres of Interest

The Newcastle Special Education Centre 